\section{Investigation of the Effect of Social Skills Training on the Motivation Levels of Preschool Children*}

\author{
Saide Özbey ${ }^{\mathrm{a},{ }^{* *}}$, Mehlika Köyceğiz ${ }^{\mathrm{b}}$
}

$\begin{array}{ll}\text { Received: } & \text { 31 January } 2019 \\ \text { Revised: } \quad 27 \text { April } 2019 \\ \text { Accepted: } \quad 29 \text { May } 2019 \\ \text { ISSN: 1307-9298 } \\ \text { Copyright (C) IEJEE } \\ \text { www.iejee.com }\end{array}$

DOI: 10.26822/iejee.2019553344

\begin{abstract}
This study was carried out in order to determine the effects of Social Skills Training Program applied to 16 children between 48 and 60 months old children's motivation levels. The social skills program included behaviors such as cooperation, social interaction, empathy, sharing, and management of feelings and social maladaptation. A personal information form and the Dimensions of Mastery Questionnaire (DMQ18) for Preschool Children were used as data collection tools in the study. Social Skills Training Program was implemented for the children for 14 weeks, two days a week. between pre-test and post-test scores. Results show that there was a significant difference in the motivation levels of the children who completed the Social Skills Training Program and the effect of the program was permanent. By considering the contribution of social skills training programs to motivation in preschool education institutions, their restructuring can be suggested. Awareness training can be provided to families for contributing to the motivation levels of children by supporting their social skills.
\end{abstract}

Keywords: Social Skills, Preschool Education, Child, Motivation

\section{Introduction}

Social skills enable an individual to express positive or negative emotions and thoughts in social environments without any loss of social support, and they have an important effect on both the social-emotional development and cognitive and academic skills of children in the long term. Failure to sufficiently develop social skills may have negative impacts throughout the whole life of a child (McCellan \& Katz, 2001; Danielson \& Phelps, 2003; Choi \& Kim, 2003).

There are several definitions of social skills based on the content covered by different fields, including social services, psychology, education, and special education programs. Social skills are a series of behaviors that can be intentionally repeated towards an objective (Bacanlı, 1999). Gresham and Elliot (1984: cit. Caldarella \& Merrill, 1997) define social skills in three different ways as behavior of children that can be accepted by peers, as responsibility in specific cases created by reducing penalties and increasing positive support, and as behavior in specific cases with positive outcomes including being popular among peers and having general acceptance in society. Samancı and Uçan (2017) describe social skills as learned behaviors that include verbal and non-verbal behaviors and that ensure that an individual start and maintains positive behaviors and develops reactions in accordance with the social environment. Social skills include problem-solving, decision-making, and self-management, and they help a child to establish and maintain positive social relations in social environments with family, friends, and schoolmates and to achieve social adaptation with easier acceptance among friends (Özyürek, 2015; Zembat, Yılmaz \& İlçi Küsmüş, 2018).

Marlowe (1986) defines social skills as the skills of an individual to understand the emotions, thoughts, and behaviors of people, including the individual himself or herself, in interpersonal situations, and the ability to behave in accordance with this understanding (cit. Genç, 2005). Social skills are the ability of an individual to demonstrate behaviors in a social environment that may be useful for the individual and others (Kozanoğlu, 2006). According to Kapıkıran, Bora İvrendi, and Adak (2005), social skills allow us to start and to maintain positive interactions with others, including communication, problem-solving, decision-making, self-management, and peer relations. Social skills are behaviors that can be observed and defined and that develop the social competence of an individual. Social skills are a part of a broad structure that is known as social competence (Warger \& Rutherford 1993; Johns, Crowley \& Guetzloe, 2005). Various factors including inheritance, family, education, and social values play an effective role in acquiring social competence. The interaction of a newborn baby with various adults, including the mother, is essential as the first step of social development. Children's social skills are negatively affected when parents' attitudes are authoritarian or permissive, and positively af fected when parents have a democratic attitude (Ogelman, Önder, Seçer \& Erten, 2013). This social interaction in the first developing years of life also has a positive effect on linguistic and cognitive development (Abalı Öztürk \& Demir, 2018; Jamison, Forston \& Stanton-Chapman, 2012; Neslitürk \& Deniz, 2014; Oden, 1987). Likewise, Kupersmidt, Voegler-Lee, and Marshall (2012) found that the academic achievements of children with poorer social skills are lower and that children with strong social skills have higher academic achievements.

Caldarella and Merrill (1997) classified social skills as relations with peers, self-control, and academic and assertiveness skills. Social skills play an effective role in the communication of an individual with both oneself and others, and in displaying several behaviors including taking responsibility, sharing, solidarity, obeying rules, making friends, solving problems, controlling emotions, and cooperating. In parallel to this, studies reveal that poor social skills are associated with increased exposure to peer victimization, inefficacy in maintaining quality and ease of daily social interaction skills, and poor academic achievement (Fox \& Boulton, 2005; Rigby, 1998; Smith \& Sharp 1994; Rigby, Simith \& Pepler, 2004; Özbey, 2009).

\footnotetext{
"This article is a publication of the BAP project, which is accepted at Gazi University.

${ }_{a,+*}$ Corresponding Author: Saide Özbey, Gazi University, Faculty of Education, Department of Basic Education, Division of Preschool Education, Teknikokullar, Ankara, Turkey. E-mail: saideozbey@gmail.com

behlika Köyceğiz, Gazi University, Graduate School of Educational Sciences, Ankara, Turkey. E-mail: mehlikakoycegiz@hotmail.com
} 
Social skills are based on individual and moral values. The values system that is deeply rooted in one's personality plays a key role in the decisions of an individual regarding how to successfully manage his or her own life (McArthur, 2002). Some values vary according to culture and time. On the other hand, core values and beliefs including integ rity, responsibility, righteousness, benevolence, respect, self-confidence, patience, self-control, and independence, which are considered to be universal and intercultural common values, guide the lives of individuals (Uyanık Balat, 2004, 2007; Uyanık Balat \& Balaban Dagal, 2007)

Lack of social skills may result in various problems in many areas for children, including self-confidence, self-control, responsibility, problem-solving, patience, persistence, perception of self-efficacy, and interpersonal relations. Social skills are the basis of social competence. Social competence is an evaluative term based on the question of whether the individual behaves in accordance with the criteria determined by the society that he or she lives in. Social competence is considered to be one of the basic human skills (Turhan \& Vuran, 2015). Lack of social skills have a negative impact on the motivation of children in both academic and social fields. Studies reveal the interrelations of motivation, social relations, and academic achievement (Dinçer, 2019; Wentzel, 1998). Motivation is a natural in strument that guides a child to discover his or her environment (Busch-Rossnagel, Knauf-Jensen \& DesRosiers, 1995; Dichter-Blancher, Busch-Rossnagel \& Knauf-Jensen, 1997). Motivation is accepted to be a product of social learning and the effective communication of an organism with the environment. Studies reveal that social environment has a significant effect on the development of top-level motivation (Messer, 1993; Morgan, Maslin-Cole, Harmon, BuschRossnagel, Jennings, Hauser-Cram \& Brockman, 2016). Looking at the characteristics of children with high levels of motivation, we notice that various qualities including patience, persistence, self-efficacy, self-esteem, positive sense of self, problem-solving, and self-control intersect with social skills. Motivation is defined as a psychological power that encourages focused and persistent independent initiatives of a person to solve a problem or achieve a moderately challenging skill or task (Morgan, Harmon \& Maslin-Cole, 1990). That psychological power prompts a child to explore from an early age. Providing children with external awards to achieve a goal in the process of curiosity, exploration, and discovery reduces internal motivation for target-oriented behaviors (Eccles \& Wigfield, 2002).

Theories that attempt to explain internal motivation can be divided into 3 categories: cognitive theory, competence theory, and association theory. Cognitive theoreticians argue that children are more prone to development when they face new and complex situations triggering their desire for exploration and discovery, and that this complexity produces internal motivation in children. According to Piaget, internal motivation is a part of the cognitive change process. When children have a new experience that cannot be assimilated in their cognitive structures, they experience cognitive imbalance. This imbalance is reduced when the child creates new cognitive structures. The noncompliance between a new stimulus and the current knowledge produces internal motivation. Cognitive theoreticians such as Piaget and Hunt state that internal motivation is a product of cognitive processing (Hunt, 1971; Mischel, 1971; cit. Gottfried, 1983). Exposure to a new environment with various stimuli increases internal motivation; however, the special stimuli producing internal motivation vary for each child since it is believed that cognitive conflict may only exist in relation with the current knowledge of the child. Therefore, environmental factors are considered to be important in internal motivation. Association theory is concerned with how children perceive the reason for their behaviors. The internal motivation of chil- dren will probably increase when they obtain a satisfactory outcome as a result of their own competence, efforts, and systematic work towards a certain goal. On the other hand, internal motivation will probably decrease when the cause of the behaviors of children is attributed to extrinsic factors including rewards, parents, and teachers rather than their own efforts. In cognitive, competence, and association theories, children are not considered to have high or low internal motivation. Rather, their motivation varies depending on the fields and conditions of certain contents that affect cognitive conflict, competence, or association. Theoreticians of competence give importance to the environment as the essence of the internal motivation of children. White (1959) recommends that children should have effective interaction with their environment and that selectiveness, persistence, and discovery are the indicators of internal motivation. Harter (1978) differentiates cognitive, social, and physical environments that may support the emergence of competence in a child and attempts to strengthen the theory of White (1959) by highlighting the role of teachers and parents in the development of internal motivation (Gottfried, 1983). Positive social support for children from their peers, teachers, and families has a positive effect on motivation (Wentzel, 1998).

In self-determination theory and cognitive evaluation theory, Deci and Ryan (1985) explain the factors in social contexts creating variance in internal motivation. Self-determination theory suggests that the supporting factors should be clearly defined in order to provide the necessary conditions for the healthy development of individuals, groups, and society. People are active creatures who have the potential to develop themselves psychological and who make efforts to overcome the obstacles they face (Ryan \& Deci, 2000). In self-determination theory, there is emphasis on psychological requirements that are accepted to be universal, including autonomy, competence, and association. These psychological needs have to be satisfied so that individuals can develop themselves. At this point, it is important that the environment of the individual supports independence. Autonomy refers to the display of behaviors by an individual by making choices. Autonomy is the acceptance, approval, and backing of an individual for his or her own behaviors and his or her guidance of these behaviors. It is more important than the needs of competence and association. The requirement for competence is defined to be the desire of an individual to have effective interactions with and positive impacts on others. The competence requirement is the sum of the acquisitions of an individual after a life of learning and his or her compliance to the environment. Acquiring a feeling of competence strengthens the self-belief of an individual to reach a goal. The requirement for association includes an individual's feeling of belonging to the social environment, and affection, respect, trust, and social-emotional acceptance in interpersonal relations (Cihangir Çankaya, 2009). The concerned feeling of belonging provides a significant contribution to the motivations of children by allowing them to develop a positive sense of self. Likewise, Türkmen and Özbey (2018) find a positive relation between the sense of self of children and their motivation levels. In his two-factor theory of 1960, Frederick Herzberg states that motivation is affected by internal and extrinsic factors. He states that the intrinsic factors affecting internal motivation are autonomy, self-realization, responsibility, and self-esteem. In other words, internal motivation is strengthened by the satisfaction of development requirements (Kaya, Yıldız \& Yıldız, 2013; Koyuncu, 2016).

Examining the theories explaining internal motivation, one can conclude that internal motivation is strengthened or weakened proportionally with the development of personality. Qualities including independence, responsibility, affection, respect, trust, positive interaction with the envi- 
ronment, and social-emotional acceptance are said to be the intrinsic factors that are effective within that process, and they can be evaluated as the social skills that an individual needs to acquire. Gresham and Elliott (1984: cit. Caldarella \& Merrill, 1997) define social skills to be behaviors of children that are accepted by peers and that have positive outcomes, including being popular among peers and general acceptance in society. Kapıkıran et al. (2005) define social skills to be the skills that allow starting and maintaining positive social relations with others, including communication, problem-solving, decision-making, self-management, and peer relations. Taking these definitions into consideration, one can conclude that the acquisition of social skills has an important role in the development and support of internal motivation, and that social skills support internal motivation and vice versa. Likewise, studies show that motivation has a significant role in predicting social competence beginning in the period of early childhood and that there is a positive relation between motivation and positive social behaviors, including social skills, self-organization, and value behaviors (Huang \& Ling Lay, 2017; Jambunathan, Burts \& Pierce, 1999; Józsa and Barett, 2018; Özbey, 2018a, 2018b; Özbey \& Aktemur Gürler, 2019).

In parallel to this idea, it is believed that the development of social skills starting from the preschool period may significantly support the internal motivation that already exists in children. Therefore, this study was conducted to reveal the extent of the effect of social skills education for preschool children on their internal motivation. This study is important as it is the first study that reveals the effect of a motivation-oriented education program in preschools, which is a new subject of study in our country.

\section{Method}

\section{Research Model}

The research included the application of a social skills education program and measured the effectiveness of this program on the internal motivation of children. Therefore, the experimental model was a one-group pretest-posttest semi-experimental design without a control group. This model is one of the pre-experimental models. In this model, the independent variable is applied to a randomly selected group. There is no randomness or matching. The design can be defined as the repeated measures design or one-factor design within groups. The design includes the testing of the significance of the differences between pretest and posttest values of a single group. The reason for excluding a control group in the study is the fact that there is no other classroom in the same age group in the school where the test group is located (Karasar, 2010). Since the test group was found to be remarkable with poor social skills and low motivation, it was selected as a group for which the Social Skills Training Program would be implemented.

\section{Study Group}

The study group in this research consisted of 16 children aged 48-60 months attending preschool. Of these children, $6.25 \%$ were 51 months old $(n=1), 18.75 \%$ were 52 months ( $n=3), 12.50 \%$ were 54 months $(n=2), 12.50 \%$ were 55 months $(n=2), 18.75 \%$ were 56 months $(n=3), 18.75 \%$ were 57 months $(n=3)$, and $12.50 \%$ were 58 months $(n=2)$. Additionally, $43.75 \%$ of the children were girls $(n=7)$ and $56.25 \%$ were boys $(n=9)$.

\section{Data Collection Tools}

A personal information form and the Motivation Scale for Preschool Children were used as the data collection tools
(Dimensions of Mastery Questionnaire: DMQ18). The personal information form included information on the demographic characteristics of the children.

The Motivation Scale for Preschool Children (DMQ18) was developed by Morgan, Maslin-Cole, Harmon, BuschRossnagel, Jennings, Hauser-Cram, and Brockman (1993). The scale was revised by Jozsa and Morgan (2015) and validity and reliability studies of the DMQ18 version of the scale were performed (Morgan, Wang, Barrett, Liao, Wang, Huan \& Jozsa, 2015). The scale is a 5-point Likert-type scale, where $1=$ not at all likely and $5=$ very likely. The scale is completed by the teachers on behalf of the children. High scores from the scale signify high motivation levels and low scores signify low motivation levels. The DMQ18 was revised in 2015 and it consists of 7 subscales including the Cognitive Persistence, Gross Motor Persistence, Social Persistence with Adults, Social Persistence with Children, Mastery Pleasure, Negative Reactions, General Competence. There are a total of 39 items in the scale. The load value of the items varies between .51 and .94 . The total variance represented by the factors is .71 .

The adaptation study of the Motivation Scale for Preschool Children for Turkish children in the age group of 36-72 months was done by Özbey and Dağlıoğlu (2017). The language validity of the scale was examined by six linguists and four academicians with a command of two languages and knowledge of the field of preschool education. Necessary adjustments were made to the scale items. Four academicians working in the field of preschool education at universities were also consulted to evaluate the scope of the scale items and their compliance with Turkish culture. The scale items were made ready for implementation after obtaining the opinions of the four specialists and they were finalized after testing for comprehensibility by five preschool teachers. The seven-factor structure of the scale was confirmed by confirmatory factor analysis. The confirmatory factor analysis included the examination of the standardized solutions and $t$ values. After the compliance indices of the scale were evaluated, it was found that the scale provides data compliance for the seven-factor structure of the adapted scale. The alpha reliability coefficients of the scale vary between.84 and .91 while the Spearman-Brown split-half test reliability coefficients vary between .77 and .90 . The test-retest reliability coefficient of the scale is .85 $(n=30)$.

In 2018, a validity and reliability study of the Motivation Scale for Preschool Children was conducted again in children aged between 36 and 72 months $(n=401)$ who attended preschools in Ankara. The seven-factor structure of the scale was confirmed after confirmatory factor analysis of the scale; the degree of freedom of the model $\chi^{2}=2311$, 91 was found to be $(d f)=681$, and $\chi^{2}=/ d f=3,39$. Among the other goodness-of-fit indices of the scale, it was found that REMSEA $=0.077, \mathrm{SRMR}=0.052, \mathrm{RMR}=0.067, \mathrm{NNFI}=$ $0.98, \mathrm{NFI}=0.97, \mathrm{CFI}=0.98$, and $\mathrm{GFI}=0.77$. When the fit indices of the scale were evaluated, data fit was achieved for the seven-factor structure of the scale and the model was found to be statistically significant $(p<.01)$ (Çokluk et al., 2010; Schermelleh-Engel, Moosbrugger \& Müller, 2003). Pearson correlation analysis was conducted to determine the interrelation of the subscales and it was found that the subscales have medium and top-level relations $(p<.01)$. The alpha reliability coefficients of the scale were found to be 0.91 for the subscale of cognitive persistence, 0.88 for the subscale of gross motor persistence, 0.90 for the subscale of social persistence with adults, 0.87 for the subscale of social persistence with children, 0.87 for the subscale of high satisfaction, 0.81 for the subscale of negative feelings, and 0.93 for the subscale of general competence. The alpha reliability coefficients of the scale in this study vary between 0.82 and 0.90 (cognitive persistence 0.90; 
gross motor persistence .90 ; social persistence with adults .90; social persistence with children .88; high satisfaction .86; negative feelings .82; and general competence .90).

\section{Implementation Process of the Program}

The Social Skills Training Program was developed by Özbey (2009). In the program development process, education programs drafted for social skills, problem-solving, and violence prevention were examined from among foreign preschool education programs for providing social skills and coping with problematic behaviors. The methods and techniques frequently used in the relevant education programs were taken into consideration. An attempt was made to create a child-centered program based on effective learning by taking contemporary education approaches into consideration, which are the sources of the basic philosophy of the 2013 Preschool Education Program. Therefore, game-based activities were planned, where children participate actively with the five senses and have fun. The social skills program was reviewed and revised based on activity planning for the 2013 Preschool Education Program.

While preparing the activities, the outcomes and indicators of the 2013 Preschool Education Program of the Ministry of National Education were selected. A part of the cards including stories and problem cases involving social skills was translated from English and the content was re-organized while taking the education program and compliance with Turkish culture into consideration. Within the scope of the social skills program, skills like communication skills, responsibility, respect, expression of feelings and emotion management, empathy, and courtesy rules were included. Opinions of three specialists on the scope of the program were obtained and the program was finalized with the recommended adjustments. The program includes 74 activities in total. Activities of the social skills program consist of those in the fields of Turkish language, music, drama, science, games, and art within an educational period of a half day. A minimum of three activities were applied within the daily education period. The implementation process of the activities varies between one hour and a half and two hours.

The motivation scale was filled in by the teacher separately for each child in order to measure their motivation lev- els before the social skills program. After the pretest, the program was applied by the researchers for 14 weeks, 2 days per week. The program was evaluated every week and the program for the next week was adjusted accordingly. The program included family participation activities, as well. After the implementation, the motivation scale was filled in again by the teacher separately for each child in order to measure the effectiveness of the program. A permanency test was conducted 4 weeks after the program was completed.

\section{Data Analysis}

The Wilcoxon signed-rank test was conducted to determine the score differences between the pretests and posttests of the children in order to determine the effects of the social skills program on the motivation levels of the children. The Friedman test was conducted to determine the difference between the pretest and permanency test. Descriptive statistics for the measurements were calculated, as well.

\section{Findings}

This section includes the analyses of the pretest-posttest and permanency tests for the Social Skills Training Program. Table 1 includes the results of the Wilcoxon signedrank test, which was conducted to determine the differences between the scores of children from the pretests and posttests.

When we examine Table 1 , it is seen that that there is a significant difference in favor of positive ranks, i.e. the posttest, among the children's scores from all subscales of the Motivation Scale questionnaire before and after the social skills education $(p<.05)$. In other words, it is possible to say that the social skills education made a significant contribution to the motivation levels of the children. Table 2 includes the results of the Friedman test, conducted to determine the differences between the scores of children from the pretest-posttest and permanency tests.

According to Table 2, there was a significant difference in motivation levels after the children received social skills training $(p<.05)$. Mutual comparisons were made between the motivation scores of the groups with the Wilcoxon signed-rank test to determine the causes of the significant

Table 1. Wilcoxon signed-rank test results for the pretest and posttest scores of the children attending social skills education based on the Motivation Scale for Preschool Children

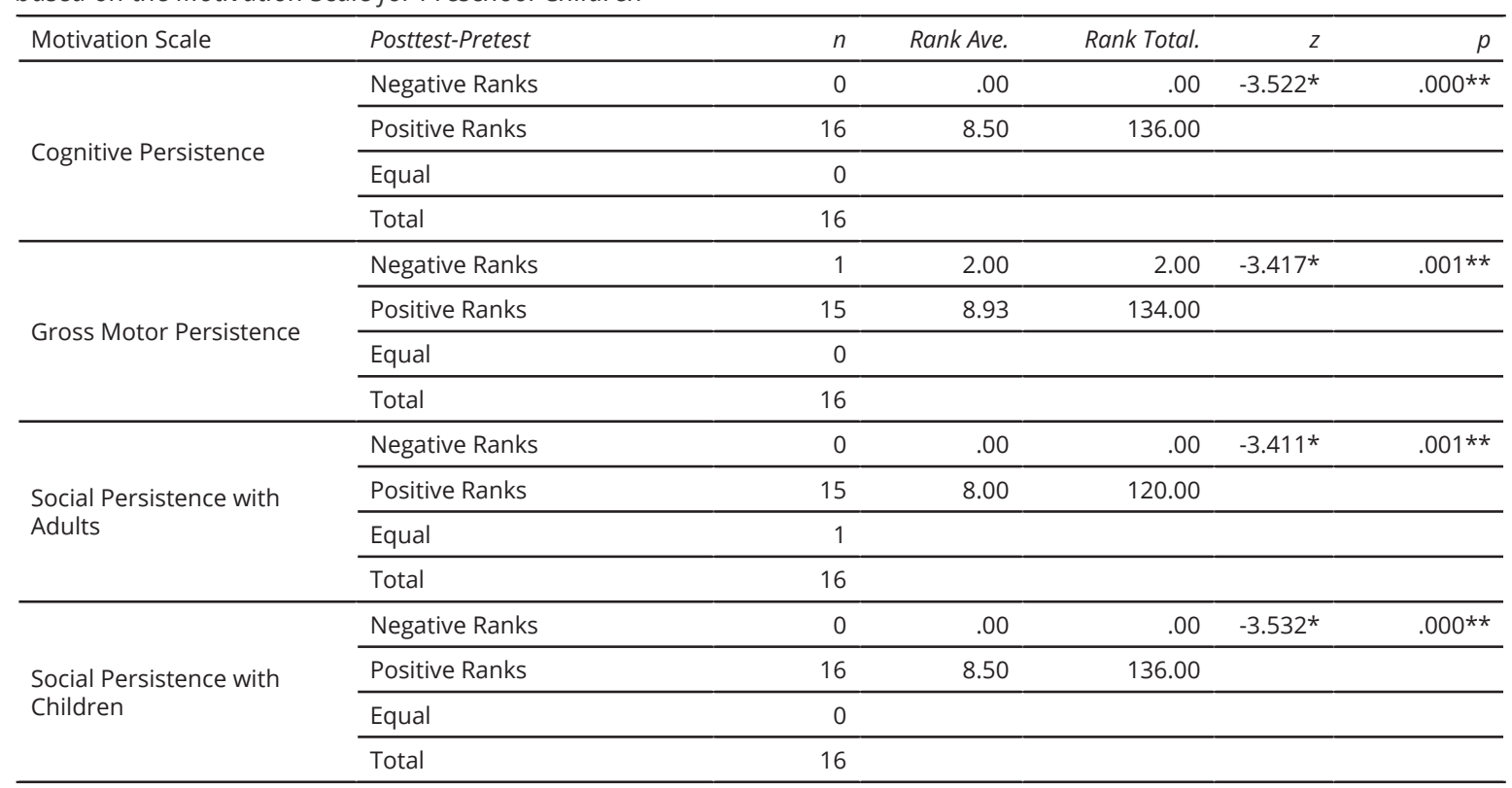


Table 1 (Cont.). Wilcoxon signed-rank test results for the pretest and posttest scores of the children attending social skills education based on the Motivation Scale for Preschool Children

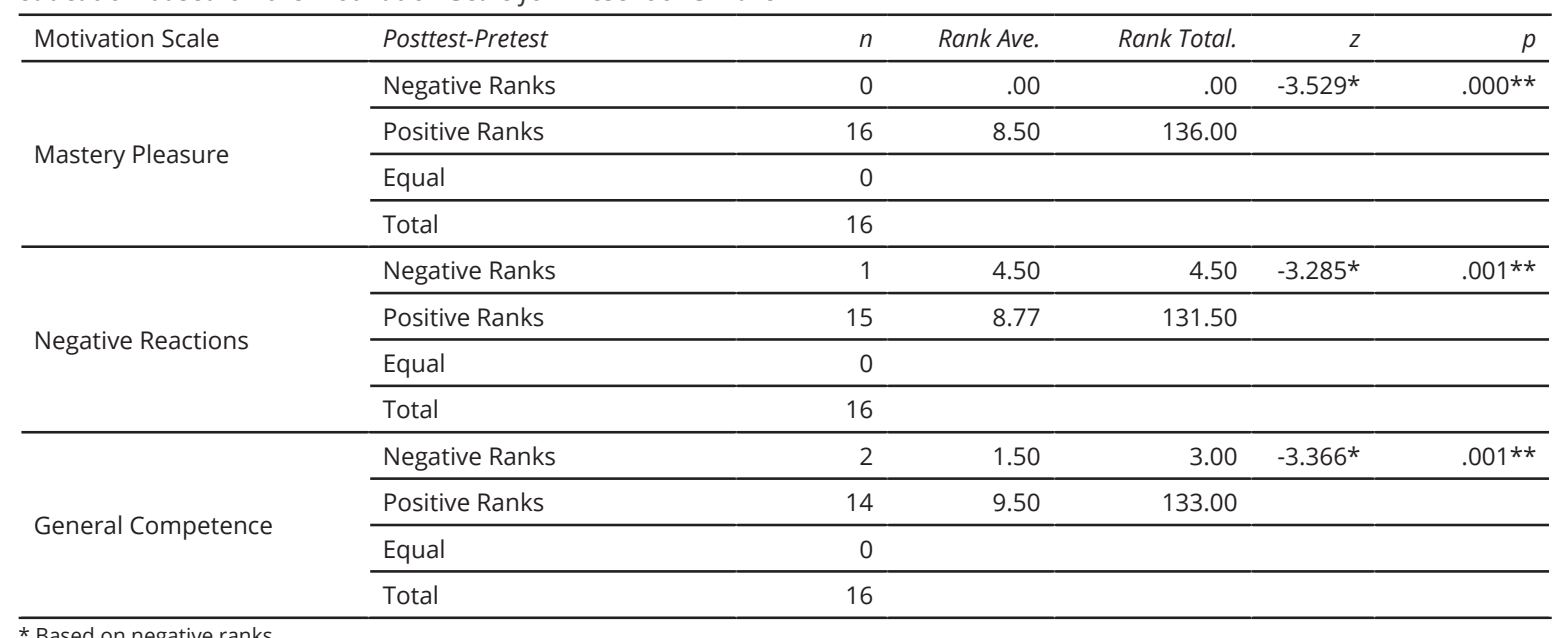

* Based on negative ranks.

**Significant difference $(p<0.05)$.

Table 2. Results of the Friedman test regarding the pretest-posttest and permanency tests according to the scores of the children attending social skills education based on the Motivation Scale for Preschool Children

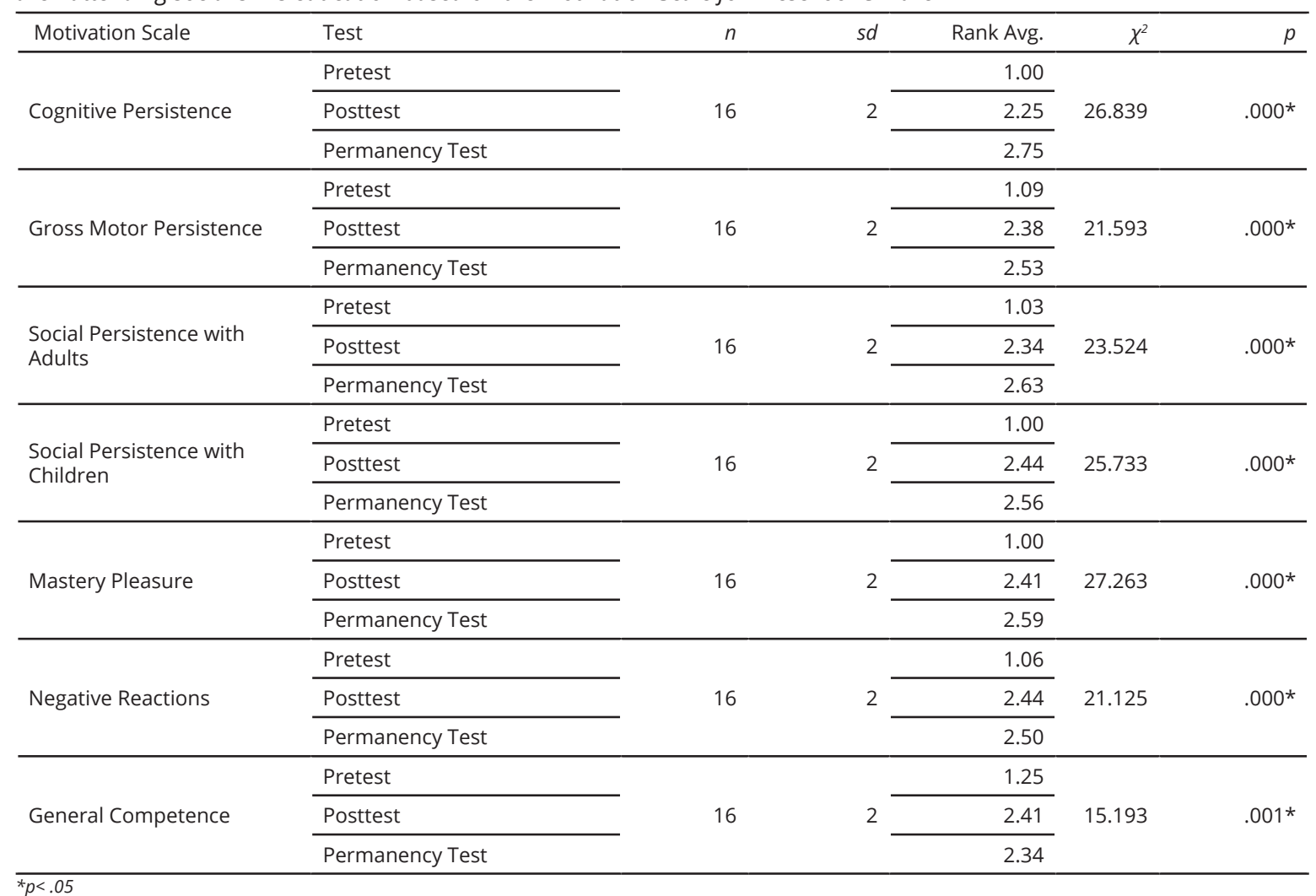

difference. As a result of the analysis, it was found that the motivation scores between the pretest and posttest were in favor of the latter and between the permanency test and pretest were in favor of the former. No significant difference was found between the posttest motivation scores and permanency test motivation scores of the children. These findings show that the Social Skills Training Program provided significant contributions to the children's motivation levels and that this contribution was permanent. Table 3 includes the Wilcoxon signed-rank test results for scores of the posttest and permanency tests that were conducted to determine the permanency of the social skills education.
When we look at Table 3, it is seen that there is no significant difference between the scores of the children from all subscales of the Motivation Scale before and after the social skills education $(p>.05)$. This result can be interpreted such that the children also maintained the increase in their motivation levels after the social skills education in the permanency test. The fact that the children also maintained the effects of social skills education on their motivation levels in the permanency test shows that the effects of the program are permanent. Table 4 includes the descriptive statistics from the pretest and permanency tests of the children receiving social skills education. 
Table 3. Wilcoxon signed-rank test results related to the scores of the posttest and permanency tests of the children attending social skills education based on the Motivation Scale for Preschool Children

\begin{tabular}{|c|c|c|c|c|c|c|}
\hline Motivation Scale & Permanency Test-Posttest & $n$ & Rank Ave. & Rank Total. & $z$ & $p$ \\
\hline \multirow{3}{*}{ Cognitive Persistence } & Positive Ranks & 11 & 6.86 & 75.50 & & \\
\hline & Equal & 2 & & & & \\
\hline & Total & 16 & & & & \\
\hline \multirow{3}{*}{ Gross Motor Persistence } & Negative Ranks & 5 & 6.40 & 32.00 & -0.551 & 0.581 \\
\hline & Equal & 4 & & & & \\
\hline & Total & 16 & & & & \\
\hline \multirow{2}{*}{ Social Persistence with Adults } & Negative Ranks & 6 & 10.00 & 60.00 & -0.416 & 0.678 \\
\hline & Positive Ranks & 10 & 7.60 & 76.00 & & \\
\hline \multirow{4}{*}{$\begin{array}{l}\text { Social Persistence with } \\
\text { Children }\end{array}$} & Negative Ranks & 5 & 6.70 & 33.50 & -0.438 & 0.662 \\
\hline & Positive Ranks & 7 & 6.36 & 44.50 & & \\
\hline & Equal & 4 & & & & \\
\hline & Total & 5 & 6.70 & 33.50 & -0.438 & 0.662 \\
\hline \multirow{4}{*}{ Mastery Pleasure } & Negative Ranks & 3 & 3.83 & 11.50 & -1.327 & 0.185 \\
\hline & Positive Ranks & 6 & 5.58 & 33.50 & & \\
\hline & Equal & 7 & & & & \\
\hline & Total & 16 & & & & \\
\hline \multirow{4}{*}{ Negative Reactions } & Negative Ranks & 8 & 8.50 & 68.00 & 0.000 & 1.000 \\
\hline & Positive Ranks & 8 & 8.50 & 68.00 & & \\
\hline & Equal & 0 & & & & \\
\hline & Total & 16 & & & & \\
\hline \multirow{4}{*}{ General Competence } & Negative Ranks & 5 & 6.00 & 30.00 & -0.892 & 0.372 \\
\hline & Positive Ranks & 4 & 3.75 & 15.00 & & \\
\hline & Equal & 7 & & & & \\
\hline & Total & 16 & & & & \\
\hline
\end{tabular}

Table 4. Descriptive statistics of scores of the children attending social skills education from the pretest and permanency tests of motivation skills

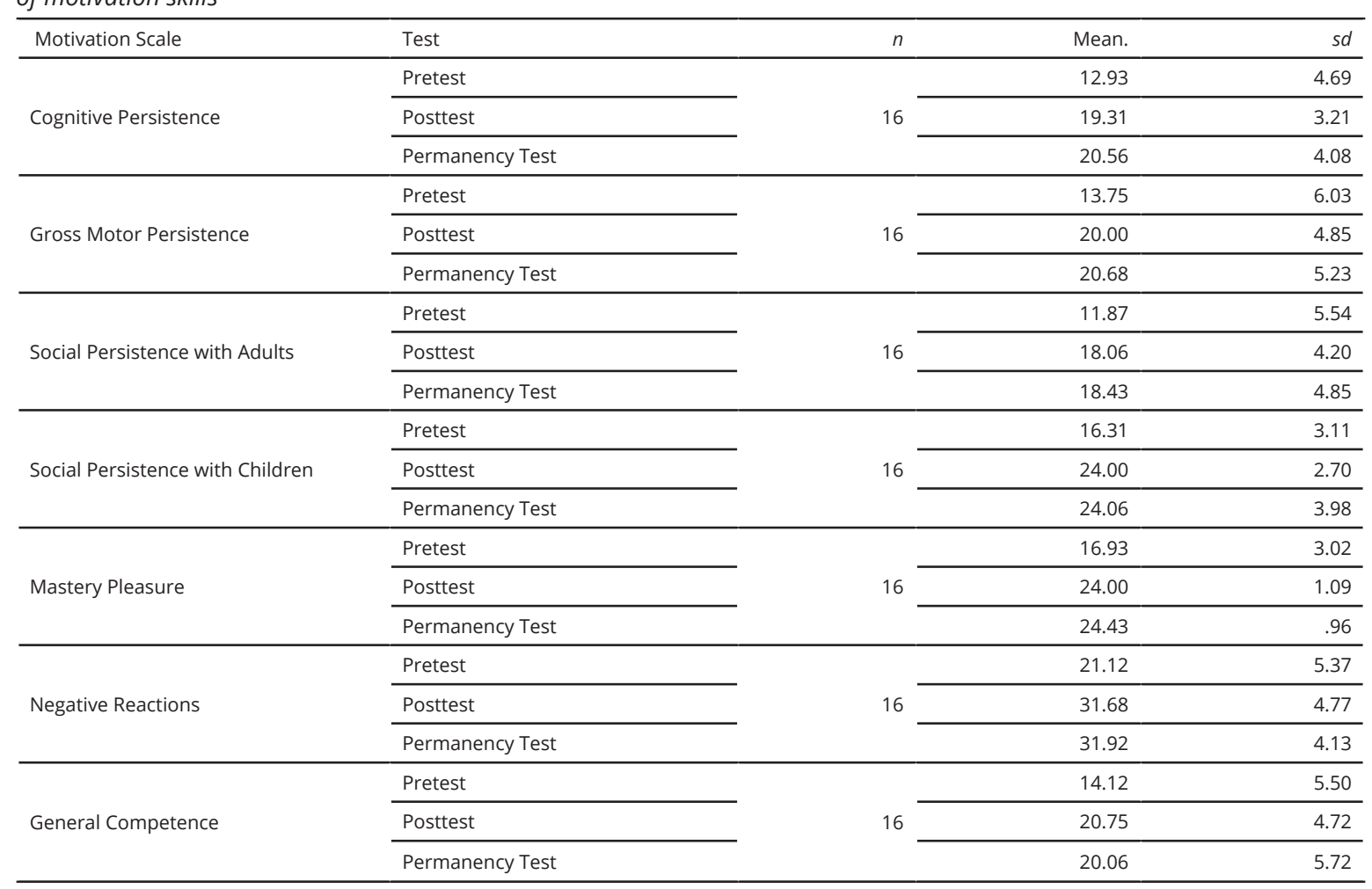




\section{Discussion and Results}

This study examined the effects of social skills education on motivation levels when applied for children aged between 48 and 60 months attending preschool. A significant difference in favor of the posttest was determined between the pretests and posttests applied to the children after the social skills education program. The permanency test showed the permanency of the education program that was applied (Tables 1-3).

In several studies on the relation between motivation and behavior, it was found that the motivation levels of children who display negative social behaviors including aggressiveness and hyperactivity were low. On the other hand, it was found that there was a positive relation between positive social behaviors and motivation levels and a negative relation between negative social behaviors and motivation levels. Earlier studies included the finding that both girls and boys with problematic behaviors have low motivation levels (Morgan, Yang, Griego, Barett \& Harmon, 1998; Goldberg, 1994).

Kowalski, Stipek, and Daniels (1987) state that children with negative behaviors are more extrinsic motivation-oriented and therefore low intrinsic motivation is related to negative social behaviors (cit. Goldberg, 1994). Özbey (2018a) found that there is a positive relation between the motivation levels and value behaviors of preschool children including responsibility, working in cooperation, and decent self-expression.

Hopp, Horn, Cheryl, McGraw, and Mayer (2000) state that the development of interpersonal skills and a sense of responsibility forms the basis for children to acquire the skill of controlling their own behaviors. Studies have demonstrated that the motivation levels of children who can control their own behaviors are high. Likewise, Özbey (2018b) and Berhenke (2013) found that there is a positive relation between the self-organization skills and motivation levels of preschool children. Lee (2014) states that self-organization and motivation are intertwined structures and emphasizes that "high level motivation and self-organization skills are umbrella structures consisting of a series of interrelated subsystems".

Wentzel (1998) states that the development of positive social relations with peers, teachers, and parents has an important effect on the motivation-related objectives of children in both academic and social fields. Studies reveal that the quality of parent-child relations and the social competence of parents have a significant contribution to the social competence of children (Guralnick, 2006; Özabacl, 2006). Wentzel (1998) found that the concerned social relations provide emotional comfort in children and strengthen the motivation that is necessary to reach academic achievement. Lee (2014) highlights that social skills and cognitive skills are able to explain the motivation sources of children and they are important in the development process. Another study directly related to this subject was conducted by Özbey and Aktemur Gürler (2019). They studied the relation between the motivation levels and social skills of preschool children and their problematic behaviors. As a result of the study, a positive relation was found between the motivation levels and social skills of the children. It was also concluded that there was a negative relation between the motivation levels and problematic behaviors of the children.

In this study, a significant difference was found in favor of the last test in the "Negative Reactions" subdimension of the Motivation Scale for Preschool Children. This finding requires further discussion. A significant increase in the negative feeling scores and the fact that children experience feelings including sadness, worry, and anger at a certain level when they fail in a task are considered to be positive. Sayığlu (2019) states that "a person may not attempt to do better due to complacency when there is no worry". Likewise, Yalçınsoy (2019) found a positive and high relation between worry and motivation. Therefore, it is possible that a certain amount of increase in negative feelings might contribute positively to the motivation levels of children.

The following recommendations can be made based on the results of this study.

Social skills guide and give meaning to the lives of children. These skills are important for children's personality development. Education on social skills is popular today; however, it is essential to study the quality of these social skills programs with regards to content. In parallel, further studies can be recommended on the development of quality social skills programs that will contribute to children's motivation levels.

In addition to education programs, there are studies that have revealed the importance of teacher efficacy on the social behaviors of children. Teacher efficacy is considered to be important for the motivation levels of children as it would undoubtedly provide positive contributions to the programs prepared by the teachers. Piştav, Akmeşe, and Kayhan (2015) found that the self-efficacy of preschool children with regards to game teaching varies significantly according to the age of the teacher and that teacher younger than 25 have higher self-efficacy in game teaching. Köyceğiz and Özbey (2018) found that the motivation levels of preschool children varied significantly depending on the university of graduation and seniority levels of teachers. In other words, they determined higher motivation levels for the children in the classrooms of teachers with higher seniority and a bachelor's degree. Upon evaluating all these studies, the importance of teacher training programs and teacher qualities comes to light. Within this scope, awareness education may be provided to preschool teachers regarding the relations of social skills education and motivation. Social skills education may also be provided for the development of intrinsic motivation. Opportunities may be created for practical social skills education programs in addition to theoretical information in teacher training programs. In-service trainings, conferences, and workshops on social skills may be recommended for teachers.

Today, as intrinsic motivation is gradually decreasing at every age and education level, educational activities can be organized for awareness of families on the effect of the development of social skills on motivation instead of choosing extrinsic motivation sources in motivating their children. Teachers and parents may be recommended to plan projects through family participation activities including education and newsletters.

In addition, researchers may be recommended to carry out further studies to determine environmental factors that contribute to motivation. Within this scope, further studies on the contributions of different education programs, classroom environments, and game materials to the motivation levels of children may be recommended.

\section{Acknowledgements}

The authors would like to thank Gazi University Scientific Research Projects Coordination Unit for supporting this research. 


\section{References}

Abalı Öztürk, Y. \& Demir, M. K. (2018). An analysis of graduate theses on early education: The case of Turkey. International Electronic Journal of Elementary Education, 10(5), 583-590.

Arnold, D. H., Kupersmidt, J. B., Voegler-Lee, M. E., \& Marshall, N. A. (2012). The association between preschool children's social functioning and their emergent academic skills. Early Childhood Research Quarterly, 27(3), 376-386.

Bacanlı, H. (1999). Sosyal beceri eğitimi. Ankara: Nobel.

Berhenke A. L. (2013). Motivation, self-regulation, and learning in preschool (Unpublished Doctoral thesis). University of Michigan

Busch-Rossnagel, N. A., Knauf-Jensen, D. E. \& DesRosiers, F. S. (1995). Mothers and others: The role of the socializing environment in the development of mastery motivation. In Mac Turk \& G. A. Morgan (Eds.), Mastery motivation: Conceptual origins and applications (pp. 117-146). Norwood, NJ: Ablex.

Caldarella, P. \& Merrill, K. W. (1997). Common dimensions of social skills of children and adolescents: A taxonomy of positive behaviors. School Psychology Rewiew, 26(2), 264-268.

Choi, D. H. \& Kim, J. (2003). Practicing social skills training for young children with low peer acceptance: A cognitive-social learning model. Early Childhood Education Journal, 31(1), 41-46

Cihangir Çankaya, Z. (2009). Özerklik desteği, temel psikolojik ihtiyaçların doyumu ve öznel iyi olma: Öz-belirleme kuramı. Türk Psikolojik Danışma ve Rehberlik Dergisi, 4(31), 23-31.

Çokluk, Ö.; Şekercioğlu, G. \& Büyüköztürk, Ş. (2010). Sosyal bilimler için çok değişkenli istatistik. SPSS ve Lisrell uygulamaları. Ankara: Pegem.

Danielson, C. K. \& Phelps, C. R. (2003). The assessment of children's social skills through self-report: a potential screening instrument for classroom use. Meas urement and Evaluation in Counseling and Development, 35(4), 18-29.

Deci, E. L. \& Ryan, R. M. (1985). Intrinsic motivation and self-determination in human behavior. New York: Plenum.

Dichter-Blancher, T. B., Busch-Rossnagel, N.A. \& KnaufJensen, D. E. (1997). Mastery motivation: Appropriate tasks for toddlers. Infant Behaviour and Development, 20, 545-548.

Dinçer, Ç. (2011) Okul öncesi dönemde sosyal beceri eğitimi. Eğitimci Öğretmen Dergisi, 5, 6-11.

Eccles, J. S. \& Wigfield, A. (2002). Motivational beliefs, values, and goals. Annual Review of Psychology, 53, 109-32.

Fox, C. L. \& Boulton, M. J. (2005). The social skills problems of victims of bullying: self, peer and teacher perceptions. British Journal of Educational Psychology, 75, 313-328.
Goldberg, M. D. (1994). A developmental investigation of intrinsic motivation: Correlates, causes, and consequences in high ability students (Unpublished Doctoral dissertation). University of Virginia, Dissertation Abstracts International, 55-04B, 1688.

Guralnick, M. J. (2006). Family influences on early development: integrating the science of normative development, risk and disability and intervention. In K. McCartney \& D. Phillips (Eds.), Handbook of early childhood development (pp.44-61). Oxford, UK: Blackwell Publishers.

Genç, S. Z. (2005). İlköğretimde sosyal becerilerin gerçekleşme düzeyinin belirlenmesi üzerine bir araştırma. Kastamonu Eğitim Fakültesi Dergisi, 13(1), 41-54.

Gresham, F. M. \& Elliott, S. N. (1984). Assessment and classification of children's social skills: A review of methods and Issues, School Psychology Review, 13, 292-301.

Gottfried, A. E. (1983). Intrinsic motivation in young children. Young Children, 39(1), 64-73.

Harter, S. (1978). Effectance motivation reconsidered: Toward a developmental model. Human Development, 21, 34-6.

Huang, S. Y \& Lay, K. L. (2017). Mastery motivation in infancy and early childhood: the consistency and variation of its stability and predictability of general competence. Hungarian Educational Research Journal, 7(2), 15-31.

Hunt, J. McV. (1971). Intrinsic motivation in psychologica development. In Personality theory and information processing. H. M. Schroeder \& P. Suedfeld (Eds.). New York: Ronald.

Hopp, M. A., Horn, C. L., Cheryl, L., McGraw, K. \& Meyer, J. (2000). Improving students ability to problem solve through social skills instruction. Degree of master of arts in teaching and leadership. Saint Xavier University \& Skylight Professional Development Field Based Master Program. Chicago, Illinois. ED 447 907.

Jamison Kristen R.; Forston, D. \& Stanton-Chapman, T. L. (2012). Encouraging social skill development through play in childhood special education classrooms. Young Exceptional Children, 15(2), 3-19.

Jambunathan, S., Burts, D. C., \& Pierce, S. H. (1999). Developmentally appropriate practices as predictors of self-competence among preschoolers. Journal of Research in Childhood Education, 13(2), 167-174.

Józsa, K. \& Barrett, K., C. (2018). Affective and social mastery motivation in preschool as predictors of early school success: A longitudinal study. Early Childhood Research Quarterly, 45, 81-92.

Johns, B. H., Crowley, E. P. \& Guetzloe, E. (2005). The central role of teaching social skills. Focus on Exceptional Children, 37(8), 1-8.

Kapıkıran, N. A, Bora İvrendi, A. \&Adak. A. (2005). Okul öncesi çocuklarında sosyal beceri: Durum saptaması. Pamukkale Eğitim Fakültesi Dergisi, 19(3) 1-8. 
Karasar, N. (2010). Bilimsel araştırma yöntemleri. Ankara: Nobel.

Kaya, F. Ş., Yıldız, B., \& Yıldız, H. (2013). Herzberg in çift faktör kuramı açısından ilköğretim 1. Kademe öğretmenlerinin motivasyon düzeylerinin değerlendirilmesi. Akademik Bakıs Uluslararası Hakemli Sosyal Bilimler Dergisi, 39, 1-18.

Koyuncu, K. (2016). Okul öncesi eğitimi öğretmen adaylarının akademik içsel motivasyonlarının çeşitli değişkenler açısından incelenmesi (Yayımlanmamış yüksek lisans tezi). Çanakkale On sekiz Mart Üniversitesi Eğitim Bilimleri Enstitüsü, Çanakkale.

Kozanoğlu, T. (2006). Utangaçlıkla baş edebilme sosyal beceri eğitimi programının ergenlerin utangaçlık düzeylerine etkisi (Yayımlanmamış yüksek lisans tezi). Çukurova Universitesi Sosyal Bilimler Enstitüsü, Adana.

Lee, J. A. (2014). The development of mastery motivation in young children. Michigan state university human development and family studies. Doctor of philosophy. Michigan State University.

Marlowe, H. A, Jr. (1986). Social intelligence: Evidence for multidimensionality and construct independence. Journal of Educational Psychology, 78, 52-58.

McArthur, J. R. (2002). The why, what, and how of teaching children social skills. The Social Studies, July/August, 183-185.

Messer, D. (1993). Mastery motivation: An introduction to theories and issues. In Messer, D. (Ed), Mastery motivation in early childhood: Development, meas urement and social processes. (pp.1-16). London: Routledge.

McClellan, D. E. \& Katz, L. G. (2001). Assessing young children's competence. Eric Identifier: ED450

Mischel, T. (1971). Piaget: Cognitive conflict and the motivation of thought. In T. Mischel (Ed.), Cognitive development and epistemology (pp. 311-335). New York: Academic.

Morgan, G. A., Maslin-Cole, C., Harmon, R. J., BuschRossnage, N. A.Jennings, K. D., Hauser-Cram, P. \& Brockman L. (2016). Parent and teacher perceptions of young children's master motivation. In Messer, D. (Ed), Mastery motivation in early childhood: Development, measurement and social processes (pp:120-129) Roudledge.

Morgan, G. A., Harmon, R. J., \& Maslin-Cole, C. A. (1990). Mastery motivation: definition and measurement. Early Education and Development, 1, 318 - 339.

Morgan, G. A., Yang, R. K., Griego, O. V., Barrett, K. C., \& Harmon, R. J. (1998). Mastery motivation in preschool children: Relations to aggression and hyperactivity. Presented at the American Educational Research Association Conference, Chicago (ERIC Document Reproduction Service No. ED 422-107).

Neslitürk, S. \& Deniz, M. E. (2014). Sosyal beceri geliştirme sistemi aile formu'nun Türk kültürüne uyarlanması: Güvenirlik ve geçerlik çalışması. Mustafa Kemal Üniversitesi Sosyal Bilimler Enstitüsü Dergisi, 11(26), 139-149.
Oden, S. (1987). The development of social competence in children ERIC Identifier: ED281610.

Ogelman, H. G., Önder, A., Seçer, Z., \& Erten, H. (2013). Anne tutumlarının 5-6 yaş çocuklarının sosyal becerilerini ve okula uyumlarının yordayıcı etkisi. Selçuk Unniversitesi Sosyal Bilimler Enstitüsü Dergisi, 29,143-152.

Özbey, S. \& Aktemur Gürler, S. (2019). Okul öncesi eğitim kurumlarına devam eden çocukların motivasyon düzeyleri ile sosyal becerileri ve problem davranışları arasındaki ilişkinin incelenmesi. UIuslararası Türkçe Edebiyat Kültür Eğitim Dergisi (TEKE), 8(1), 587-601.

Özabacı, N. (2006). Çocukların sosyal becerileri ile ebeveynlerin sosyal becerileri arasındaki ilişki üzerine bir araştırma. Fırat Universitesi Sosyal Bilimler Dergisi, 16(1), 164.

Özbey (2018a). Okul öncesi dönem çocuklarının ahlaki değer davranışları ile motivasyon düzeyleri arasındaki ilişkinin incelenmesi. Uluslararası Eğitim Bilimleri Dergisi, 5(16), 1-15.

Özbey, S. (2018b). Okul öncesi dönem çocuklarında motivasyon ve öz düzenleme becerileri üzerine bir inceleme. Akademik Sosyal Araştırmalar Dergisi, 6(65), 26-47.

Özbey, S. \& Dağlıoğlu, E. (2017). Adaptation study of the motivation scale for the preschool children (DMQ18). International Journal of Academic Research, 42(1), 1-14

Özbey, S. (2009). Anaokulu ve anasınıfı davranış ölçeği'nin (PKBS-2) geçerlik güvenirlik çalışması ve destekleyici eğitim programının etkisinin incelenmesi (Yayımlanmamış doktora tezi). Gazi Üniversitesi Eğitim Bilimleri Enstitüsü, Ankara.

Özyürek, A. (2015). Okul öncesi çocuklarin sosyal beceri düzeyleri ile anne tutumları arasındaki ilişkinin incelenmesi. Milli Eğitim Dergisi, 45(206), 106-120.

Piştav Akmeşe, P. \& Kayhan, N. (2017). Özel eğitim öğretmenlerinin oyun öğretimine ilişkin öz-yeterlik düzeylerinin incelenmesi. Ankara Üniversitesi Ĕgitim Bilimleri Fakültesi Özel Eğitim Dergisi, 18(1), 1-26.

Rigby, K. (1998). Bullying in schools and what to do about it? Markham, Ont.: Pembroke Pub.

Rigby, K.; Simith, P. K. \& Pepler, D. (2004). Working prevent school bullying key Issues. In Peter Smith; Ken Rigby \& Debra Pepler (Eds). Bullying in schools: How successful can interventions be? (pp.1-13). Publisher: Cambridge University.

Ryan, R. \& Deci, E. (2000). Self - Determination theory and the facilitation of Intrinsic motivation, social development and well- being. American Psychologist, $55(1), 68-78$

Samancı, O. \& Uçan, Z. (2017). Çocuklarda sosyal beceri eğitimi. Atatürk Üniversitesi Sosyal Bilimler Enstitüsü Dergisi, 21(1), 281-288.

Sayıoğlu, C.(2019). Kaygı motivasyonu düşürüyor. https:// www.kigem.com/kaygi-motivasyonu-dusuruyor. $\mathrm{html}$ 
Smith, P. \& Sharp, S. (1994). School bullying: Insights and perspectives. Publisher: Taylor \& Francis, Inc.

Schermelleh-Engel, K., Moosbrugger, H., \& Müller, H. (2003). Evaluating the fit of structural equation models: Tests of significance and descriptive goodness-of-fit measures. Methods of Psychological Research, 8(2), 23-74.

Turhan, C., \& Vuran, S. (2015). Otizm spektrum bozukluğu gösteren çocuklara sosyal beceri öğretiminde sosyal öykü ve video model uygulamalarının etkililik ve verimlilikleri. International Journal of Early Childhood Special Education, 7(2). 294-315.

Türkmen S. \& Özbey S. (2018). 60-72 Aylık okul öncesi dönem çocuklarının benlik algılarının bazı değişkenler ve motivasyon düzeyi ile ilişkisinin incelenmesi. Social Mentality and Researcher Thinkers Journal, 4, 606-620.

Uyanık Balat, G. (2004). Çocuklar ve değerler eğitimi. Çoluk Çocuk Dergisi, 45, 18-20.

Uyanık Balat, G. (2007). Değerler eğitimi ve değerler eğitimi programları. Ayla Oktay \& Özgül Polat Unutkan (Eds.) Okul öncesi dönemde güncel konular (s. 197209). İstanbul: Morpa Kültür.

Uyanık Balat, G. \& Balaban Dagal, A. (2007). Okul öncesi dönemde değerler eğitimi etkinlikleri. Ankara: Kök.

White, R.W. (1959). Motivation reconsidered: The concept of competence. Psychological Bulletin, 66, 297-33.

Wang, J. \& Barrett, K. C. (2013). Mastery motivation and self-regulation during early childhood. K. C. Barrett, N. A. Fox, G. A. Morgan \& L. A. Daunhauer (Eds.), Handbook of self-regulatory processes in development: New directions and international perspectives. (pp. 337-380). New York: Psychology.

Warger, C. \& Rutherford, R. (1993). Preventing school failure. Alternative Education for Children and Youth, 37(4) 21-27.

Wentzel, K. R. (1998). Social relationship and motivation in middle school: the role of parents, teachers and peers. Journal of Educational Psychology, 90(2), 202209.

Yalçınsoy, A. (2017) Yaşam doyumu, kaygi ve motivasyon ilişkisi ile ilgili üniversite gençliğine yönelik bir araştirma: Dicle üniversitesi örneği. II. Uluslararası Sosyal Bilimler Sempozyumu Kongre Kitabı (s.30593071).https://www.researchgate.net/publication/322071612.

Zembat, R., Yılmaz, H., \& Küsmüş, G. İ. (2018). Okul öncesi dönem çocuklarının mizaç özellikleri ile sosyal becerileri arasındaki ilişkinin incelenmesi. Serkan Dinçer (Ed), Değişen dünyada eğitim (s.43-56). Ankara: Pegem. 